\title{
ジャンパー膝に対する運動後のアイシングの効果
}

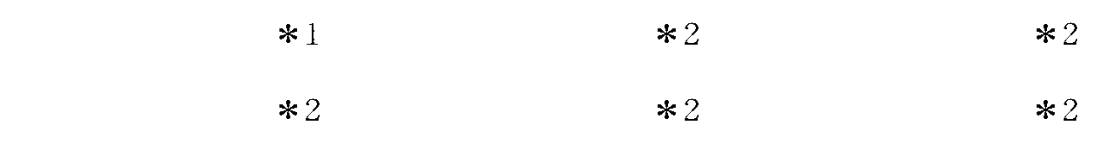

\section{THE EFFECTS OF ICING AFTER EXERCISE ON JUMPER'S KNEE}

\author{
Ren Ayata, Hitoshi ShiRaki, TAKashi Fukuda, MASAhiro TAKEMURA, \\ NAOKI MUKAI and SHUnPEI MiYAKAWA
}

\begin{abstract}
The purpose of this study was to investigate the pathologic changes of jumper's knee before and after jumping and effects of icing after jumping. Sixteen healthy college students and sixteen collegiate volleyball players with jumper's knee were divided into two groups by eight, without icing group and with icing group after jumping exercise. Without icing groups rested for 20 minutes, while with icing groups were treated with ice for 20 minutes after eighty times of jumping. Signal to noise ratio (SNR) and sectional area of patellar tendon with Magnetic Resonance Imaging and the tenderness of patellar tendon with visual analog scale were measured before and after exercise, following with or without icing and 24 and 48 hours later from the treatment. In jumper's knee group, significant increase was found in the SNR, sectional area of patellar tendon, and tenderness of patellar tendon after exercise compared to before exercise. In addition, in jumper's knee with icing group, significant decrease was found in the SNR, sectional area of patellar tendon after icing and 24 and 48 hours after icing, and the tenderness of patellar tendon after icing compared to after exercise. These results suggested that icing was an effective treatment for jumper's knee after exercise.
\end{abstract}

(Jpn. J. Phys. Fitness Sports Med. 2007, $56: 125 \sim 130$ )

key word : jumper's knee, jump, after care, icing

I . 緒言

ジャンパー膝は, ジャンプ, 着地 , ストップ , ダ ッシュが頻繁に繰り返され, 膝伸展機構(大腿四頭 筋腱一膝蓋骨一膝蓋腱) に過度の負荷がかかると で引き起こされる障害である゙'. 発症の要因として は, 膝伸展機構にかかる過度の負荷とともに, 練習 の頻度や時間，技術，下肢筋力のバランス，大腿四 頭筋の柔軟性などが, 複合的に作用していることが 考えられる ${ }^{2)}$.

ジャンパー膝の画像診断において, Magnetic Resonance Imaging (以下 MRI)では腱の損傷部位に異 常信号が認められるとされている1).しかし, 診断 目的で撮像されていることがほとんどであるため， 本症の病態を MRI などの画像を用いて経時的に評
価した研究は少ない。

また，ジャンパー膝は根本的な治療法が確立され ておらず,症状が長引くことの多い障害である ${ }^{1,3) . ~}$ 現在では, アイシング , ストレッチング , テーピン グ , 筋力トレーニングなど樣々な処置がジャンパー 膝に対して行われており ${ }^{2,3)}$, 特にアイシングはス ポーツ現場において，幅広く実施されている．

アイシングの影響や効果については, 多くの臨床 的な研究が行われている ${ }^{4)}$.しかし，これらの多く は健常者を対象として行った研究であり，実際に障 害を起こしている例に対するアイシングの効果を具 体的に検討したものは少ない．また，ジャンパー膝 に対するアイシングの効果の詳細な研究も見あたら ない

本研究ではジャンプ動作前後のジャンパー膝の病

\footnotetext{
*1) 甲南大学スポーツ・健康科学教育研究センター 干658-0032 兵庫県神戶市東灘区向洋町中8-2

*2) 筑波大学人間総合科学研究科 干 305-8577 茨城県つくば市天王台 1-1-1

Education and Research Center for Sports and Health Science, University of Konan Graduate Course of Comprehensive Human Science, University of Tsukuba
} 
態変化, 及びジャンプ動作後のアイシングの効果に ついて MRI を用いて検討し，ジャンパー膝に対す るアイシングの有用性を明らかにすることを目的と した

$$
\text { II. 方法 }
$$

\section{A. 対 象}

膝関節及び大腿部に既往のない健常成人 16 名 (男 性11名 女性5名, 平均身長 $168.6 \pm 7.34 \mathrm{~cm}$, 平均 体重 $64.9 \pm 10.23 \mathrm{~kg}$, 平均年齢 $23.3 \pm 1.08$ 歳)の踏 み切り脚 (以下健常膝群), ジャンパー膝の症状 (Blazina の分類 : ステージII) を有する大学バレー ボール選手16名 (男性11名 女性 5 名, 平均身長181.4 $\pm 8.17 \mathrm{~cm}$, 平均体重 $73.3 \pm 8.20 \mathrm{~kg}$, 平均年齢 20.7 \pm 1.01 歳)の患側の脚 (以下ジャンパー膝群)とした . ジャンパー膝の疼痛部位は膝蓋骨下端部の膝蓋腱付 着部である者が10名, 脛骨粗面の膝蓋腱付着部であ る者が 6 名であった .

全ての被験者に対して, 本研究の趣旨と内容を十 分に説明した上で、文書による実験参加の同意を得 た。なお, 本研究は筑波大学体育科学系研究倫理委 員会の承認を得て実施した .

\section{B. 測定項目}

1. MRI 撮像

永久磁石型 MR イメージング装置(日立メディコ 社製)を用いて膝蓋腱部の撮像を行った . 撮像中の 肢位は仰臥位, 膝関節軽度屈曲位とした . 安静時に ペンで撮像部位にマークをしたうえで，マーカーを 貼付することにより，膝蓋腱部の撮像部位が毎回同 一となるようにした .

1) signal to noise ratio (以下 SNR)

SNR とは信号雑音比のことである .これはノイ ズの変動に対する信号の大きさを表したものであ り5), MRIの 画像上では,

SNR 大`高信号 $<$ 信号大 $>\fallingdotseq$ 高輝度

となると考えられる . ジャンパー膝のMRIを用いた 画像診断においては正常な膝蓋腱が低輝度像である のに対して, 高輝度像である膝蓋腱は微細な断裂， 粘液变性, 炎症などの腱自体の病变が疑われる ${ }^{6,7)}$. 以上より, 本研究では, ジャンプ動作やアイシング の影響によるジャンパー膝の病態の変化について検
討するため，この SNR を病態の評価方法として用 いた。

撮像には gradient echo 法による T2* 強調画像 (TR $500 \mathrm{~ms}$; TE $34 \mathrm{~ms}$; マトリックス $260 \times 224$; FOV $200 \mathrm{~mm}$; スライス厚 $4 \mathrm{~mm}$; スライス幅 $5 \mathrm{~mm}$ ; 積算回数 4 回; 撮像時間 7 分 28 秒) を用いた . 撮 像面として, 膝蓋腱に直交する矢状断像を得た。 得られた T $2 *$ 強調画像より，MRI 装置に内蔵され ているソフトウェアを用いて膝蓋腱部の SNR(任意 単位)を求めた。1つの画像に対して SNR の算出 を 3 度行い, 平均值を光の画像の SNR とした。

2) 膝蓋腱断面積

撮像には gradient echo 法による T2* 強調画像 (TR $500 \mathrm{~ms}$; TE $34 \mathrm{~ms}$; マトリックス $224 \times 200$; FOV $160 \mathrm{~mm}$; スライス厚 $4 \mathrm{~mm}$; スライス幅 $5 \mathrm{~mm}$ ; 積算回数 4 回; 撮像時間 6 分 40 秒)を用いた。撮 像面として, 膝蓋腱に直交する水平断像を得た . 得られた T $2 *$ 強調画像より，画像解析用ソフトウ ェア ImageJ を用いて膝蓋腱の断面積 $\left(\mathrm{mm}^{2}\right)$ を求め た. 1 つ画像に対して断面積の算出を 3 度行い， 平均値を谷の画像の腱断面積とした .

\section{2 . 圧 痛}

Hand-Held Dynamometer(HOGGAN 社製 MICRO 一FET)を利用した自作の圧痛計を用いて膝蓋腱部 の主観的な圧痛を測定した．圧迫部位はジャンパー 膝群では患部，健常膝群では膝蓋腱の中央部とし， 圧迫の強さは $60 \mathrm{Nm}$ とした .

評価にはVisual Analog Scale(以下V AS)を用い， Scale は 1 <痛まない>から 0.5 刻みで $5<$ くなり 痛む〉までの 9 段階とした .

\section{C. 実験プロトコール}

SNR, 膝蓋腱断面積, 圧痛をジャンプ動作前 (以 下ジャンプ前)，ジャンプ動作後(以下ジャンプ後)， アフターケア後 (以下 $\mathrm{AC}$ 後), アフターケア 24 時 間後 (以下 $\mathrm{AC} 24$ 時間後), アフターケア 48 時間後 (以下 $\mathrm{AC} 48$ 時間後)に測定し, 経時的変化を比較 検討した。

ジャンプ動作は , バレーボールの 1 試合平均ジャ ンプ数を参考とし, 全力のスパイクジャンプを15秒 間隔で80回行った。

また，アイシングの効果を評価するために，健常 膝群, ジャンパー膝群ともに 8 名ずつランダムに , 
ジャンプ後アフターケアを行わない群(以下健常膝 C 群, ジャンパー膝 $\mathrm{C}$ 群) と, アフターケアとして アイシングを行う群(以下健常膝 I 群, ジャンパー 溙 I 群)に分け, 乥れ朰れ比較検討した。

\section{D. アフターケアの内容}

\section{1 . 無処置}

ジャンプ後20分間の安静(アフターケアは行わな

い)を仰臥位にて行った .

$$
\text { 2.アイシング }
$$

ジャンプ後ゴム水囊にキューブアイスをつめて作 つたアイスパックを用い，20分間膝蓋腱への冷却を 仰臥位にて行った 。

\section{E. 評価方法}

測定項目に対するジャンプ動作の影響を検討する ために, 各測定項目のジャンプ前とジャンプ後の測 定值を，健常膝群とジャンパー膝群产れ光れにおい て比較した .

アイシングの効果を検討するために，各測定項目 のジャンプ後の測定値を基準とし, $\mathrm{AC}$ 後, $\mathrm{AC} 24$ 時間後, $\mathrm{AC} 48$ 時間後の測定值におけるジャンプ後 に対する変化率, (各測定值ージャンプ後の測定值) ハジャンプ後の測定值 $\times 100$ を求め, 経時的変化を健 常膝 C 群, 健常膝I群, ジャンパー膝 C 群, ジャンパー 膝 I 群の光れ光れにおいて比較した。

\section{F． 統計処理}

各測定項目の值は, 平均及び標準偏差で表した . ジャンプ前とジャンプ後の比較には, 対応のある $\mathrm{t}$ 検定を用いた . 経時的変化の比較には, 分散分析及 びFisher's PLSD を用いた。なお，検定の有意水準 は $5 \%$ 末満とした .

$$
\text { III. 結果 }
$$

\section{A . ジャンプ動作前後の比較}

健常膝群ではSNR, 膝蓋腱断面積, 膝蓋腱の圧 痛いずれもジャンプ前とジャンプ後の測定值に有意 差は認められなかった .

ジャンパー膝群ではジャンプ前に比ベ, ジャンプ 後に SNR, 膝蓋腱断面積, 膝蓋腱の圧痛の増加が 認められた(図 $1,2 ， 3 ， 7$ )。

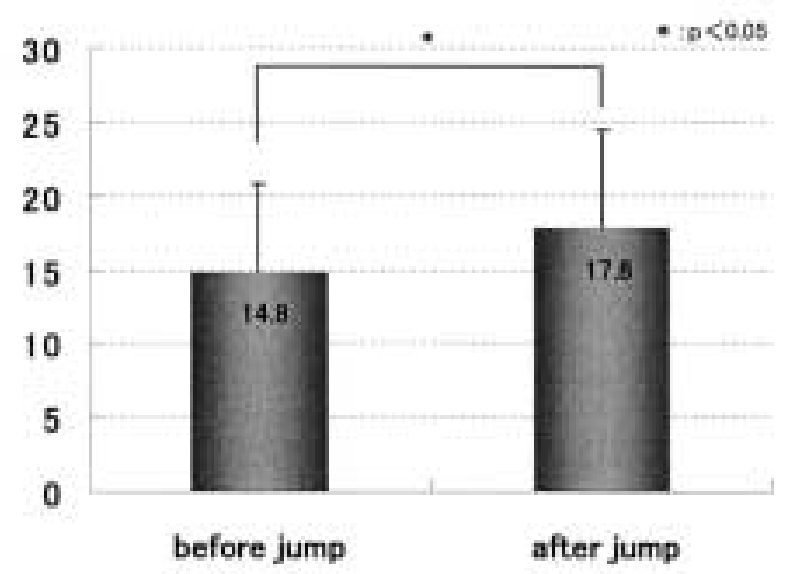

Fig. 1. Comparison between before jump and after jump of SNR in Jumper's knee group.

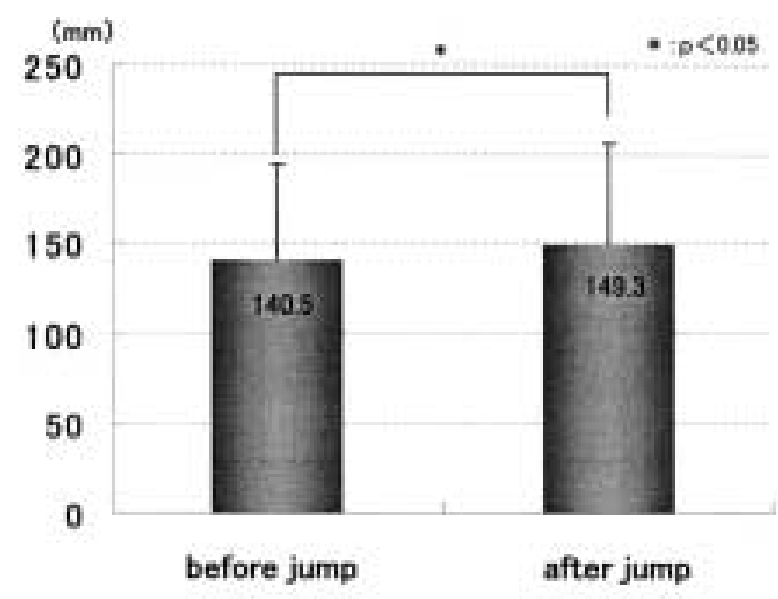

Fig. 2. Comparison between before jump and after jump of sectional area of patella tendon in Jumper's knee group.

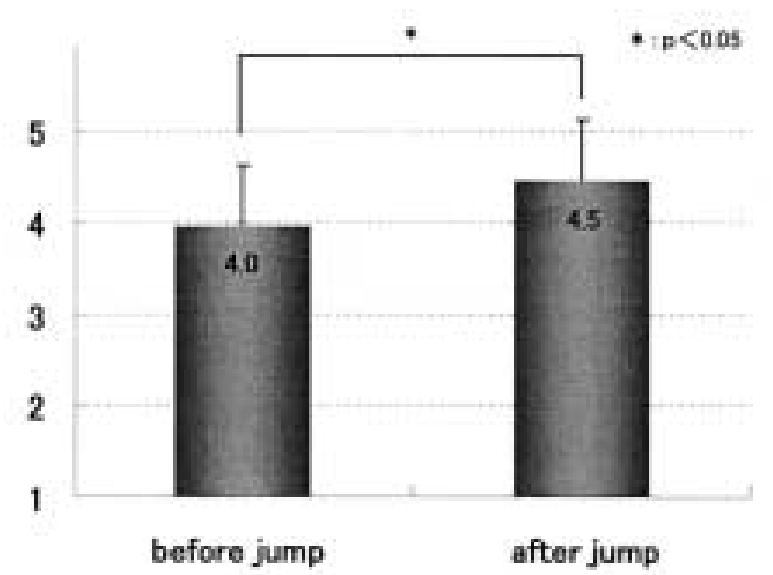

Fig. 3. Comparison between before jump and after jump of tenderness in Jumper's knee group.

B. ジャンプ後から AC48 時間後までの経時的 変化の比較

健常膝 C 群, 健常膝 I 群, ジャンパー膝 C 群では 


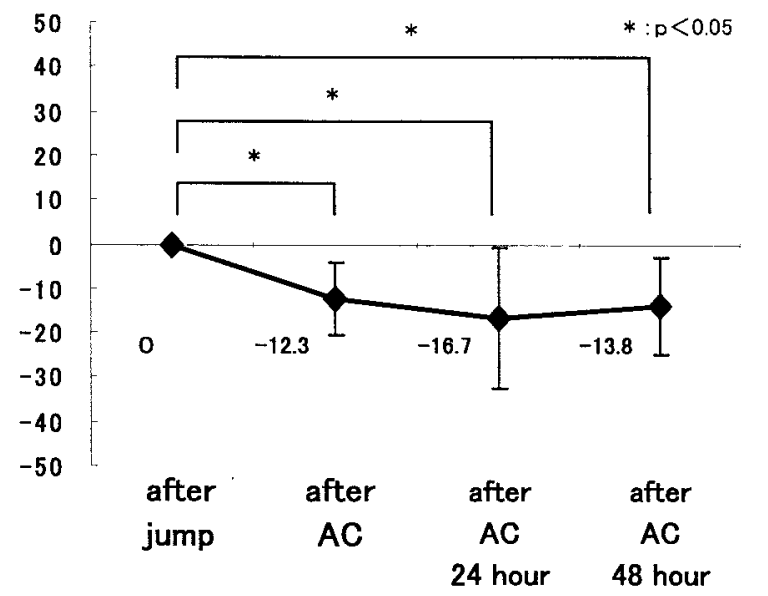

Fig. 4. Change over time in the SNR in Jumper's knee with icing group.

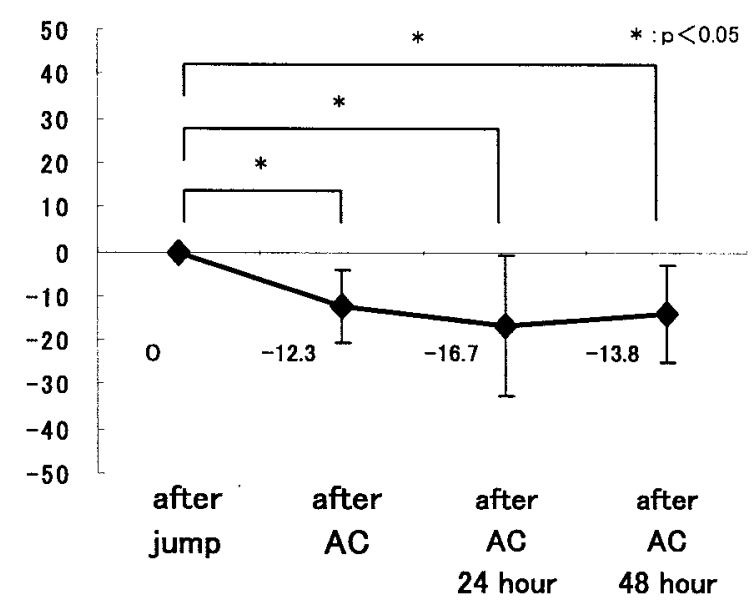

Fig. 5. Change over time in the sectional area of patella tendon in Jumper's knee with icing group.

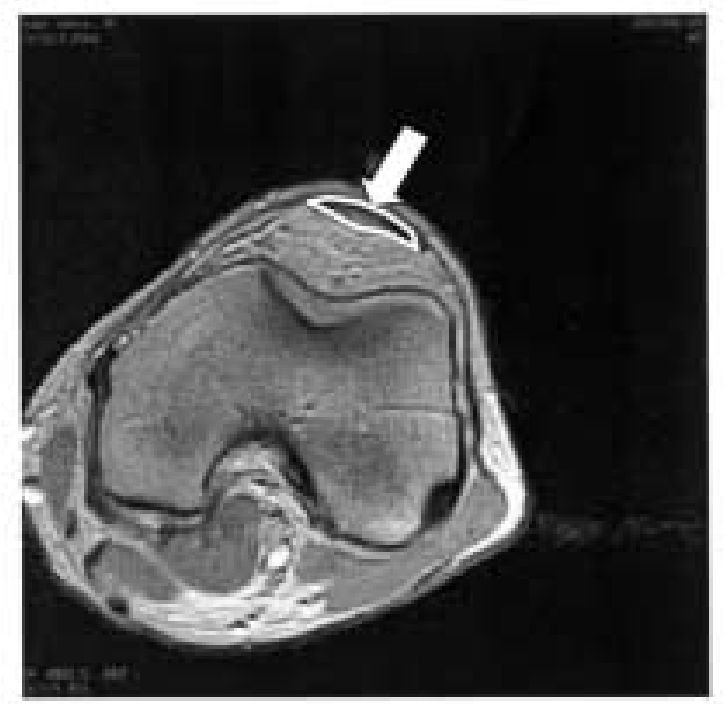

before jump

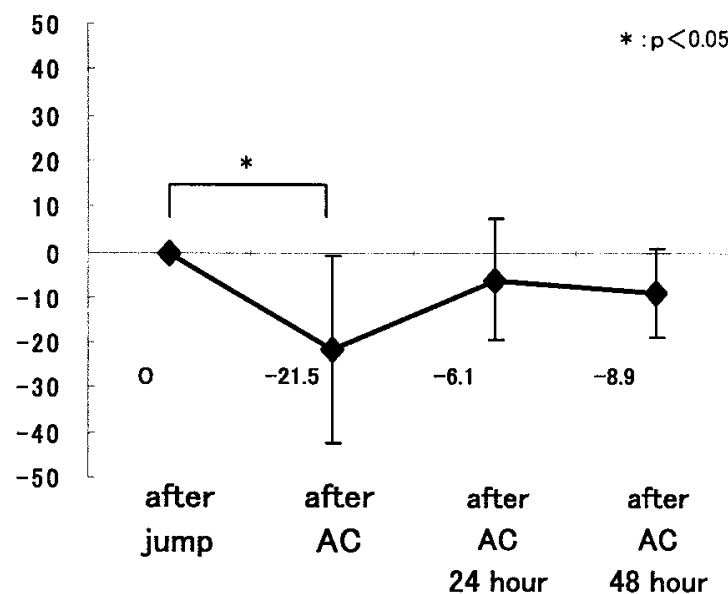

Fig. 6. Change over time in the tenderness in Jumper's knee with icing group.

SNR，膝蓋腱断面積，膝蓋腱の圧痛いずれも経時的 変化に有意差は認められなかった .

ジャンパー膝 I 群ではジャンプ後に比べ, $\mathrm{AC}$ 後 , $\mathrm{AC} 24$ 時間後, AC48 時間後に SNR, 膝蓋腱断面積 の減少, $\mathrm{AC}$ 後に患部の圧痛の減少か認められた(図 $4,5,6,8)$.

$$
\text { N. 考察 }
$$

A．ジャンプ動作が健常膝及びジャンパー膝に及 ぼす影響

ジャンパー膝群では SNR，膝蓋腱断面積，患部 の圧痛の増加が認められた．つまり，ジャンプ後の

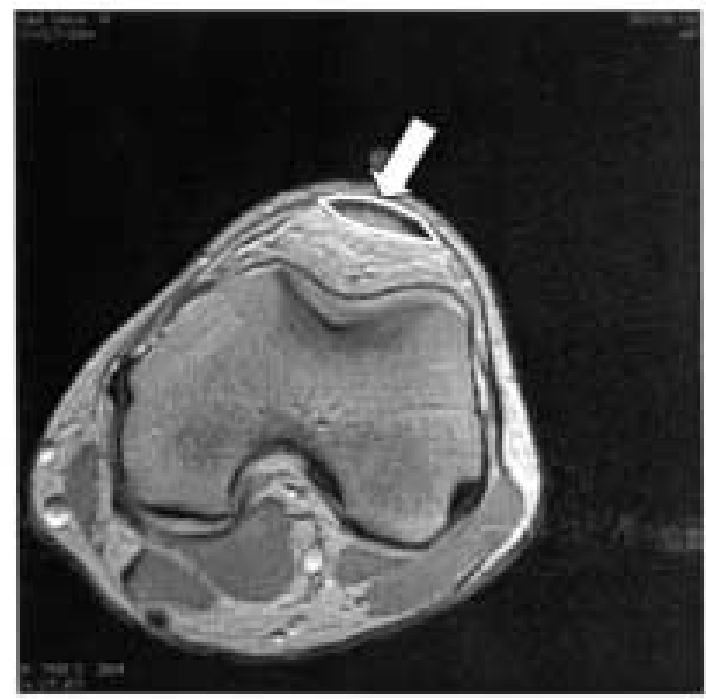

after jump

Fig. 7. This figure is example of transverse section imaging of jumper's knee group. Sectional area of patellar tendon (area of encircled with line) was measured before and after jump. Sectional area swelled after jump compared to before jump. 


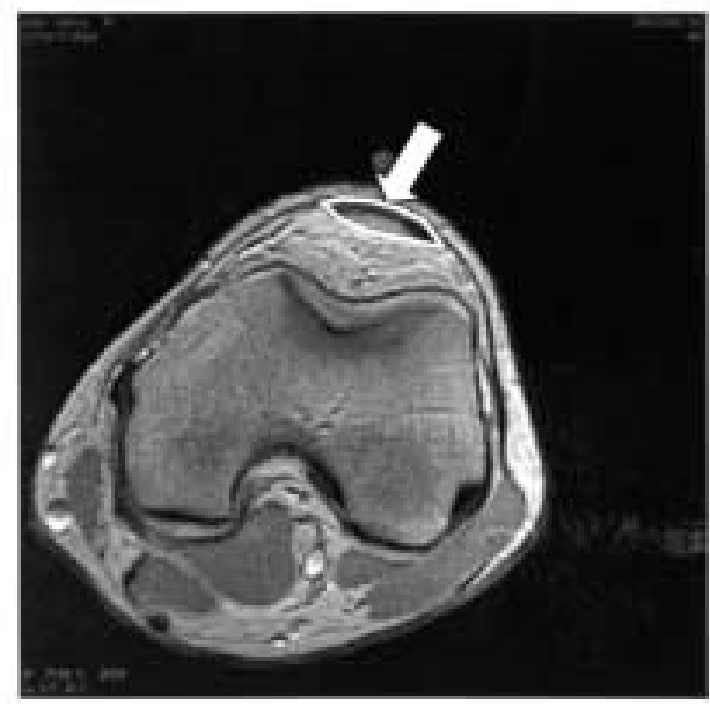

after jump

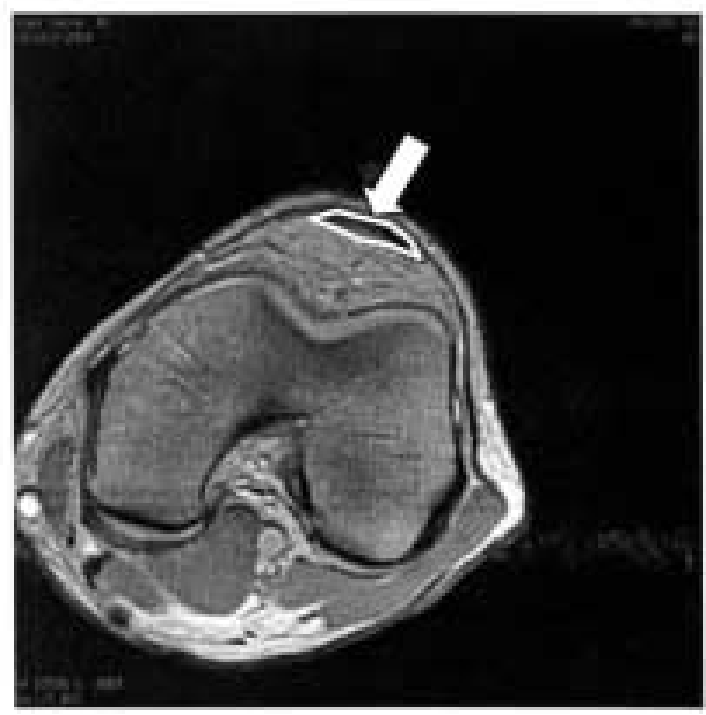

after AC 24 hour

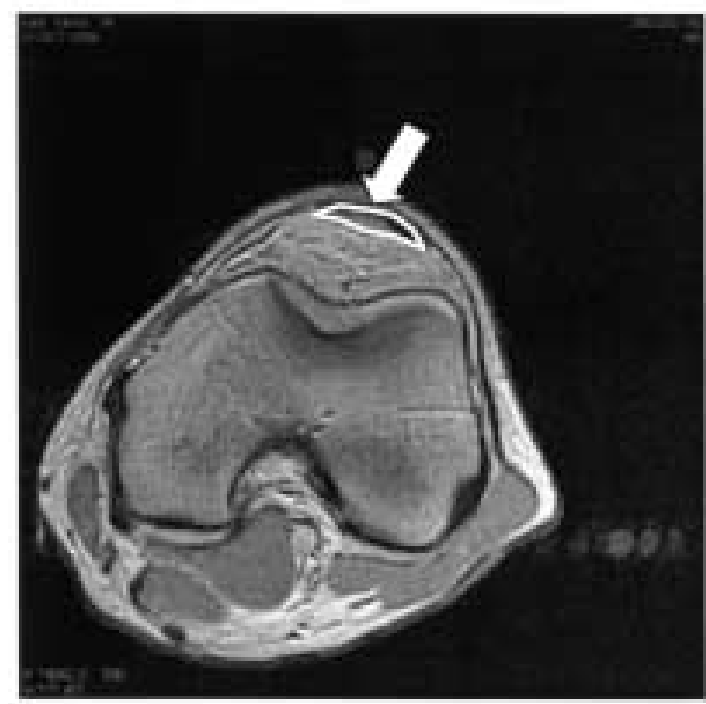

after AC

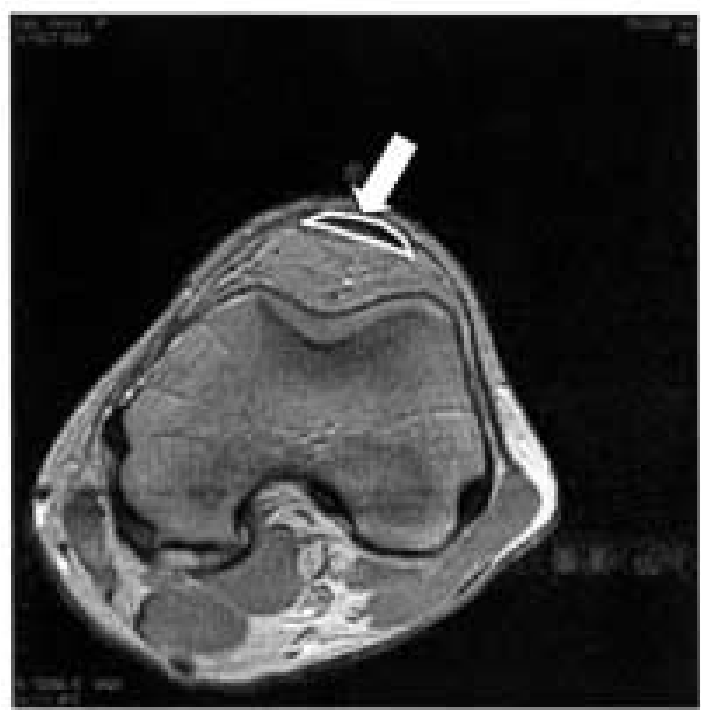

after AC 48 hour

Fig. 8. This figure is example of transverse section imaging of jumper's knee with icing group. Sectional area of patellar tendon (area of encircled with line) was measured after jump, after AC, after AC 24 hour, and after AC 48 hour. Sectional area narrowed after AC, after AC 24 hour, and after AC 48 hour compared to after jump.

MRI 像より，ジャンパー膝群の膝蓋腱には, ジャ ンプ動作によって何らかの変性が生じたと言える. これらのことから , ジャンパー膝の発症過程でおこ る , ジャンプ動作による大腿四頭筋からの大きな育 引ストレスによって生じた膝蓋腱の微細な断裂や7 8)，二れによって生じる腱内や腱表層の出血 ${ }^{1)}$, 腱 細胞の浸透圧の上昇による組織内の浮腫の形成 ${ }^{5)}$ が, 慢性期の病態でもおこっていると考えられる . また，浮腫など水分含量の多い部分は, $\mathrm{T} 2 *$ 強調
画像において高輝度を呈すると報告されており8)， 本研究の結果を支持するものである.したがって， 本研究においてもこのような出血や浮腫によって膝 蓋腱が肥大し, ジャンプ後の MRI 像で高輝度像が 呈され，断面積と圧痛か増加したと考えられる。

B. アイシングが健常膝及びジャンパー膝に及ぼ す影響

ジャンプ後を基準とした全ての測定項目におい 
て, 健常膝 C 群, 健常膝I群, ジャンパー膝 C 群で は有意な経時的変化は認められなかったことに対 し , ジャンパー膝 I 群ではジャンプ後に 20 分間のア イシングをすることで, $\mathrm{AC}$ 後 $\mathrm{AC} 24$ 後 $\mathrm{AC} 48$ 後に SNR の減少, 膝蓋腱断面積の減少, $\mathrm{AC}$ 後に 患部の圧痛の減少か認められた .つまり，アイシン グは健常膝には影響を及ぼさなかったが, ジャン パー膝には影響を及ぼしたと考えられる．

過去の研究において, MRI 像の輝度が低下する とともに患部の臨床症状も緩和したと報告されてい る ${ }^{9)}$.このことから, ジャンパー膝 I 群において， 輝度の低下により SNR が減少したということは， アイシングによって患部の炎症などの臨床症状が緩 和したと言える . Knight et al. は, アイシングは炎 症谷のものに作用するのではなく，炎症に伴ってお こる浮腫を軽減すると報告している ${ }^{4)}$.よって，本 研究においても, このアイシングによる浮腫の軽減 によって, ジャンパー膝 I 群では患部の輝度の低下 と, 膝蓋腱断面積の減少が生じたと考えられる。

また，アイシングの効果の一つに疼痛の緩和が挙 げられる ${ }^{4)}$.これはアイシングによって，神経の伝 達速度が低下して痛みの閾值が上昇することや，組 織の代謝の低下により二次的低酸素症を抑制するこ とによって生じるものであると報告されている ${ }^{4)}$. 本研究においてもこの効果によって, ジャンパー膝 I 群でアイシング後に圧痛が減少したと考えられ る。

\section{C. 総合考察}

本研究の MRI 像から, 健常膝群においてはジャ ンプ動作の反復による膝蓋腱実質の明らかな変性は 認められなかったが, ジャンパー膝群においては認 められた .この変性は, 膝蓋腱の微細な断裂や炎症 によるものと考えられる ${ }^{1,7)}$. また, ジャンパー膝 群の圧痛がジャンプ後に増加しているという結果か らも，この変性は疼痛を誘発させるものであり，ジ ヤンパー膝を悪化させるものと考えられる .

ジャンプ後にアイシングを行うことは, 健常膝 I 群には全く影響を及ぼさなかった。しかし, ジャン パー膝I群に対しては, 膝蓋腱の SNR や断面積, 圧 痛を減少させた .この結果から，アイシングによっ てジャンパー膝の悪化か抑制されたと言え，これは アイシングがジャンパー膝に対する非常に効果的な
アフターケアであるということを示している . ジャ ンパー膝である選手は, 症状があるにも関わらず， ジャンプの反復を繰り返し，膝蓋腱に過負荷をかけ るため,少しずつ症状が悪化していく場合が多い）。 アフターケアとしてアイシングを用いることは , こ れらの抑制に対しても非常に有効であると考えられ る。

$$
\text { V. 結 論 }
$$

A . ジャンパー膝群において, SNR, 腱断面積 , 圧痛がジャンプ前に比ベジャンプ後に有意に増 加していた .

B . 健常膝 C 群, 健常膝 I 群, ジャンパー膝 C 群 において , 全ての測定項目でジャンプ後の経時 的変化に有意差は認められなかった .

C . ジャンパー膝 I 群において, SNR, 腱断面積 がジャンプ後に比べ $\mathrm{AC}$ 後, $\mathrm{AC} 24$ 後, $\mathrm{AC} 48$ 後に有意に低下していた．また，圧痛がジャン プ後に比べ $\mathrm{AC}$ 後に有意に低下していた .

(受理日 平成18年 9 月 16 日)

文献

1) 林 光俊, 石井良章, スポーツ外傷・障害の理学診 断・理学療法ガイド ジャンパー膝, 臨床スポーツ 医学 臨増, (2001)，18，273-280。

2) 村田量優，畠中拓哉，バレーボール選手に対するス ポーツ理学療法, 理学療法, (2001), 18(12), 11671176 .

3) 米田 進，スポーツ競技復帰と理学療法一競技別傷 害特性と理学療法の実際 バレーボール, 理学療法, (1998)，15(10)，826-832.

4) Kenneth L. Knight , クライオセラピー , 初版 , ブッ クハウス HD，東京，(1997)。

5) 小倉明夫, 宮井 明, 前田富美恵, MR 画像の SNR に関する基礎的検討，日本放射線技術学会誌，(2003)， 59(4) , 508-513.

6) 越智光夫, 宗田 大, 数面義雄, MRI て理解する膝 の外傷・障害,初版, 南江堂, 東京, (2002), 140-145.

7) 德谷 聡, 岡村良久, 星 忠行, スポーツ選手にお けるジャンパー溙の手術成績, 整形外科, (1998)，49 (13)，1663-1667.

8) 加家壁正和, 高岸憲二, 鈴木慶子, Patellar tendinitis の MRI, 日本整形外科スポーツ医学会雑誌, (2000), 20(2), 146 .

9）長沢浩治，野口昌彦，平澤泰介，いわゆるアキレス 腱炎・腱周囲炎一 MRI 所見からの考察一, 整形・災 害外科，(1999)，42(5)，583-589. 